\title{
Anatomical-embryological correlates in atrioventricular septal defect
}

\author{
SALLY P ALLWORK* \\ From the Department of Surgery, Division of Cardiovascular Disease, Royal Postgraduate Medical School, \\ Hammersmith Hospital, London
}

SUMMARY Recent embryological studies have supported the consideration that the ventricular septum is multifocal in origin. These data have also provided excellent correlation of the morphology of malformed hearts with their embryology. In particular, atrioventricular septal defect correlates accurately with these observations on ventricular septation. Many of the names given to atrioventricular septal defect (for example ostium primum, persistent atrioventricular canal, endocardial cushion defect) indicate attempts at correlating the anatomy with embryology. None of these has been very convincing.

In the light of this uncertainty, this review considers briefly the anatomy of the malformation and its ontogeny, and presents a hypothesis of the development of atrioventricular septal defect.

Although there is almost always a communication above the atrioventricular valves, the malformation lies in the ventricular, not the atrial septum. Hearts with inlet septal defect without interatrial communication represent one end of the spectrum of anomalies, and those with common atrioventricular orifice, in which Fallot's tetralogy or single outlet heart may be associated, mark the other end. The outflow tract malformations are not randomly associated, but are points in a huge range of cardiac malformations.

Atrioventricular septal defect is a cardiac malformation characterised externally by an abnormally short posterior (diaphragmatic) ventricular surface. ${ }^{1}$ Internally there is a gap between the concave inferior rim of the atrial septum (which is usually well developed) and the atrioventricular valves. There may be a common atrioventricular valve, usually with five or six leaflets of which the two major ones, anterior and posterior, bridge the ventricular septum. ${ }^{2}$ Often there are two valves, each with three leaflets ${ }^{3}$ (Fig. la, b). The left component has an abnormally orientated anterior leaflet which is separated medially from the septal or posterior leaflet by an unsupported division which is usually called a cleft. Between the anterior and septal leaflets, at the obtuse margin, is the lateral leaflet (Fig. 1b). When there is a bridging leaflet between either the anterior and lateral, or posterior and lateral leaflets, it produces an accessory orifice, and is common in atrioventricular septal defect. ${ }^{13}$ The

^Supported by the British Heart Foundation.

Accepted for publication 27 November 1981 leaflets themselves are often poorly developed and may have a verrucous appearance.

The short external diaphragmatic surface of the ventricular mass is reflected internally by a pronounced disproportion between the inlet and outlet lengths of the left ventricle. In normal hearts these two measurements are essentially the same. ${ }^{1}$ In atrioventricular septal defect the outflow tract of the left ventricle is long and narrow compared with a normal heart (Fig. 2a, b) and the left anterior leaflet inserts immediately behind and beneath the aortic valve so that the latter is displaced. (Whether the valve is really displaced has been debated at length ${ }^{4-6}$ but the appearance is that of displacement.) It has lost its wedged position between the atrioventricular valves and the ventricular septum. ${ }^{78}$ Sometimes aortic outflow tract obstruction occurs, and muscular obstruction may be further aggravated by hypoplasia of the aortic valve. 9

Pulmonary outflow tract obstruction is especially associated with a common valve with bridging leaflets $^{2}$ and may be the result of the infundibular 419 


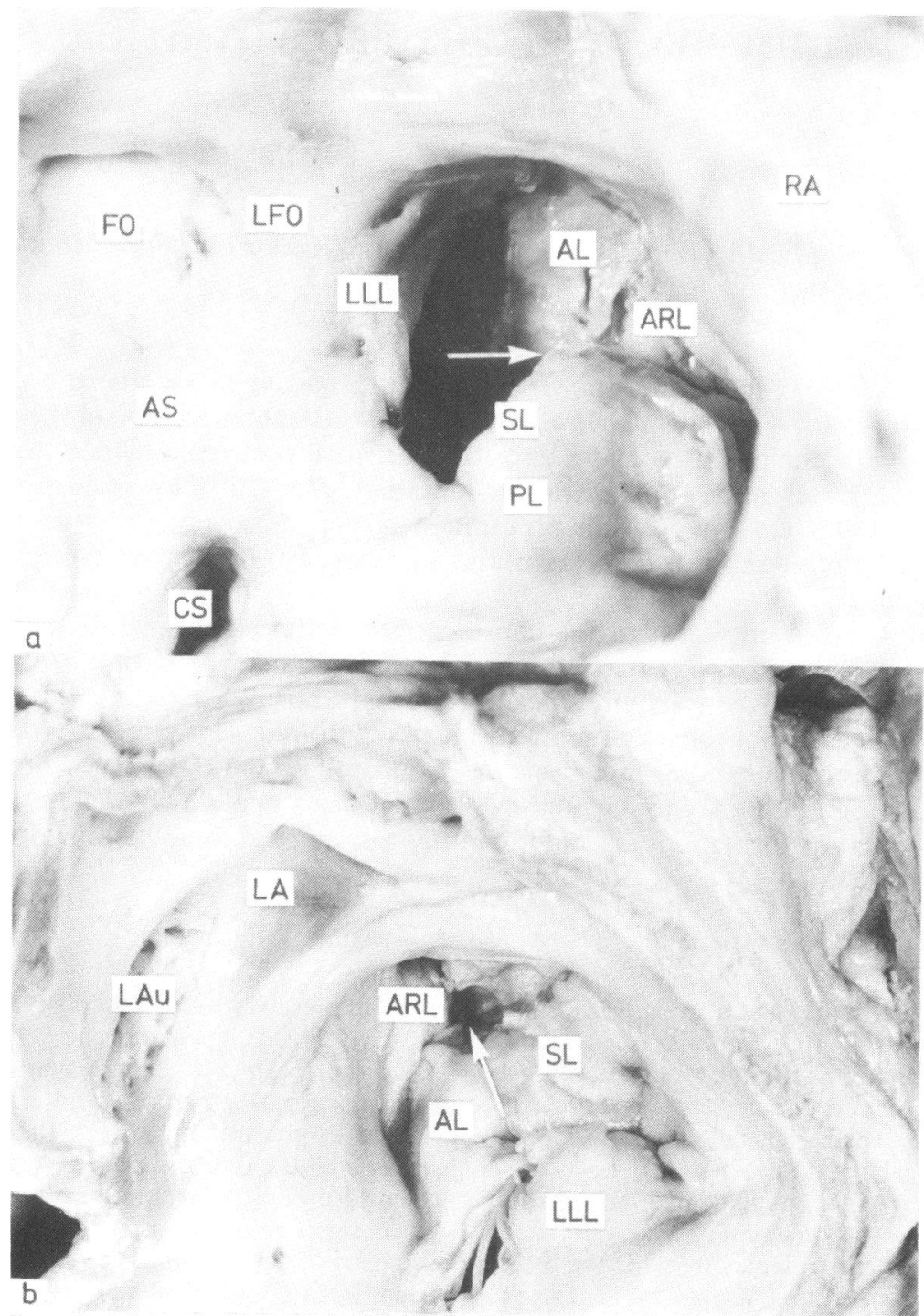

Fig. 1 (a) The atrioventricular valves in atrioventncular septal defect (AVSD) seen from the right atrium $(R A)$. The atrial septum $(A S)$ is intact and its concave rim forms the "roof" of the AVSD. The valve leaflets are attached at the same level to the summit of the muscular septum, but the anterior $(A L)$ and posterior $(P L)$, or septal $(S L)$ bridging leaflets are separated by the "cleft" (arrowed). LLL, lateral left leaflet; ARL, anterior right leaflet; CS, coronary sinus; FO, fossa ovalis; LFO, limbus fossa ovalis. (b) Same heart, left atrial (LA) view. The left valve does not resemble a normal mitral valve. It has three leaflets, anterior, septal or posterior, and lateral. The abnormally orientated anterior leaflet is separated by the cleft (arrowed) from the septal or posterior bridging leaflet. LAu, left auricle. Other abbreviations as in Fig. 1(a). 


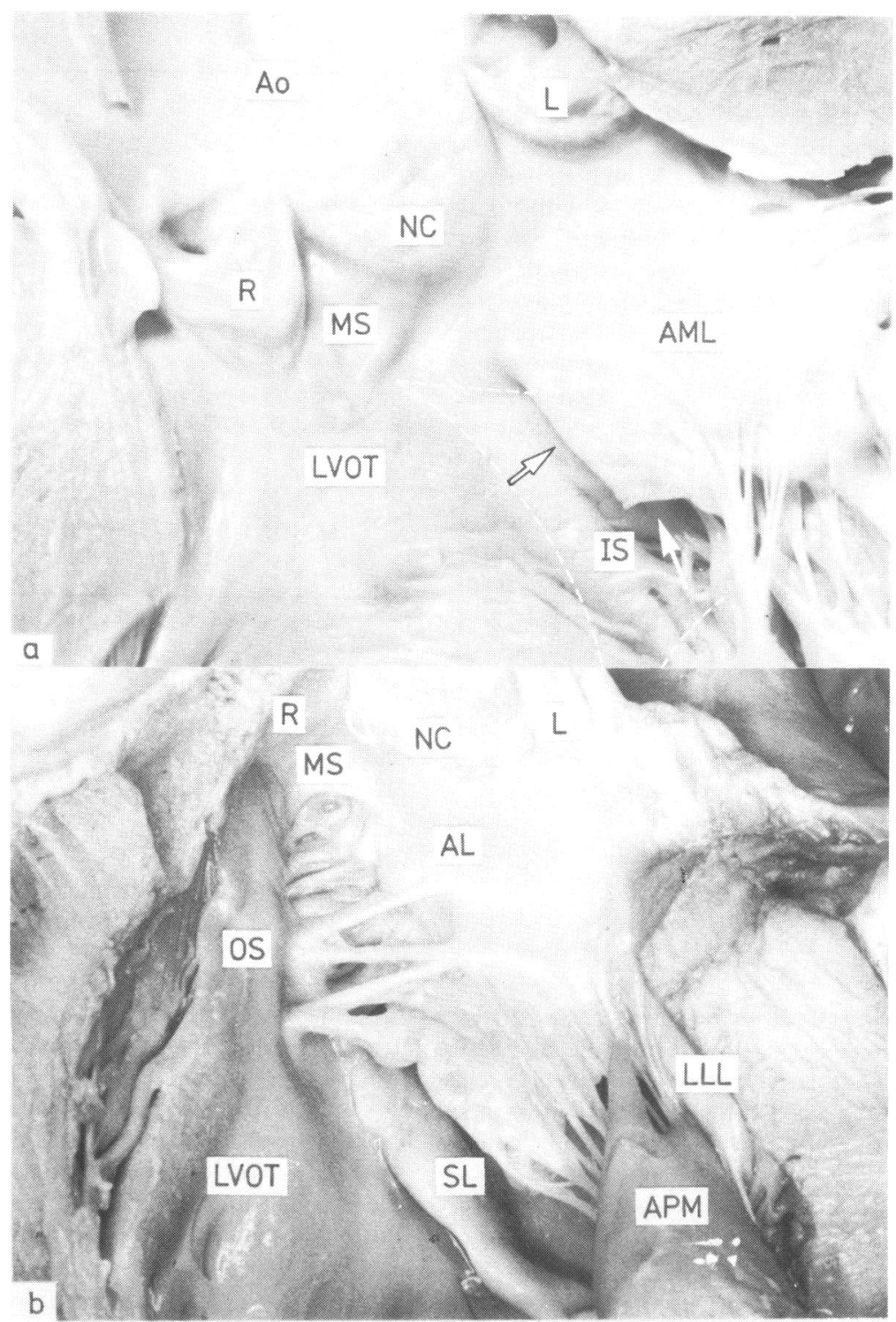

Fig. 2 (a) The left ventricular outflow tract in the normal heart. The inlet septum (IS) and its atrioventricular component, indicated by the dotted line, give "depth" to the outflow tract. The atrioventricular septum extends from the membranous part of the septum $(M S)$ to the crux cordis permitting a posterior recess (arrowed). The anterior mitral leaflet $(A M L)$ is normally orientated, and extends from the base of the left aortic leaflet $(L)$ to the non-coronary leaflet (NC). Thus the aortic valve is "wedged" by the inlet septum and the mitral valve, so that it lies beside rather than anterior to the mitral valve. Ao, aorta; LVOT, left ventricular outflow tract; $R$, right aortic leaflet. (b) The left ventricular outflow tract in AVSD. The narrowness is partly the result of the deficiency of the inlet septum and absence of its atrioventricular component (note the septal attachment of the anterior leaflet $(A L)$ of the left valve) and partly of attenuation of the outlet septum (OS). The loss of the normal "wedge" position of the aortic valve is shown by the position of the anterior leaflet which extends from the left aortic leaflet to the commissure between non-coronary and right $(R)$ leaflets. The membranous part of the septum is small, but intact. APM, anterior papillary muscle group. Other abbreviations as in Fig. 1. 
ogy. Double outlet right ventricle, ventriculoarterial discordance, and single outlet heart are also sometimes represented in atrioventricular septal defect. ${ }^{10-12}$

The atrial septum is usually well developed in atrioventricular septal defect; the anticipated normal anatomical elements are represented and atrial septation is often complete, especially in those with "partial" or "transitional" defects (Fig. la and b). Patency of the foramen ovale, however, occurs with some frequency, as in the normal heart, and secundum atrial septal defects are common. In view of the frequent finding of a normal atrial septum it is, perhaps, surprising that so many investigators have concluded that the development of this structure is at fault in atrioventricular septal defect. The defect itself is the gap between the inferior rim of the atrial septum and the atrioventricular valves. The vertical dimension of this defect is approximately the same as the disproportion between the inlet and outlet length of the ventricular septum measured in the left ventricle (Table 1). These data strongly suggest that the anomaly concerns the inlet ventricular septum rather than the atrial septum.

The foregoing paragraphs are not intended to be an exhaustive description of atrioventricular septal defect, but to indicate the spectrum which can accurately be correlated with the ontogeny of the ventricles and the ventricular septum.

\section{Historical background}

Atrioventricular septal defect was first described by Peacock ${ }^{13}$ who considered imperfect ventricular septation to be involved in the anomaly. In view of recent embryological findings, Peacock's view is of some interest, as many of those who followed him considered only defective or arrested septation to be responsible. The history of the terminology and the gross classification are summarised in Table 2.
Table 2 Nomenclature and morphology in atrioventricular septal defect

Peacock ${ }^{13} 1846$

Rokitansky ${ }^{14} 1875$

Watkins and Gross ${ }^{16} 1955$

Wakai and Edwards ${ }^{17} 1956$

Bedford et al. 181957

Brandt et al. ${ }^{19} 1972$

Piccoli et al. ${ }^{56} 1979$

ASD, atrial septal defect; VSD, ventricular septal defect.

With respect to "partial" and "complete" defects, most authors have adhered to Rokitansky's ${ }^{14}$ division $\odot$ between those with interatrial communication only ? (partial) and those who had an interventricular defect as well. ${ }^{15-19}$ More recently, however, the two terms have been used to distinguish between separated atrioventricular (partial), and common orifice (complete), ${ }^{5-6}$ but this distinction has not gained gen- $\mathbb{Q}$ eral currency, especially in surgical practice. ${ }^{23}$ Wakai and Edwards ${ }^{20}$ described a third type of atrioventricu- $\frac{\text { O }}{3}$ lar septal defect which they termed "transitional" or "intermediate". These hearts had two "cleft" atrioventricular valves and a "narrow bridge of valvular tissue in the midline (which) joins the anterior half $\widehat{\infty}$ of each of the two cleft atrioventricular valvular leaflets with their respective posterior halves just above the ventricular septum". In four of the six. hearts which they described there was a small interventricular communication as well. Thus the "transi-

Table 1 Measurements of inlet and outlet septa in left ventricle, and of vertical dimension of defect in 10 hearts with atrioventricular $\frac{T}{O}$ septal defect, situs solitus, and concordant ventriculoarterial connections

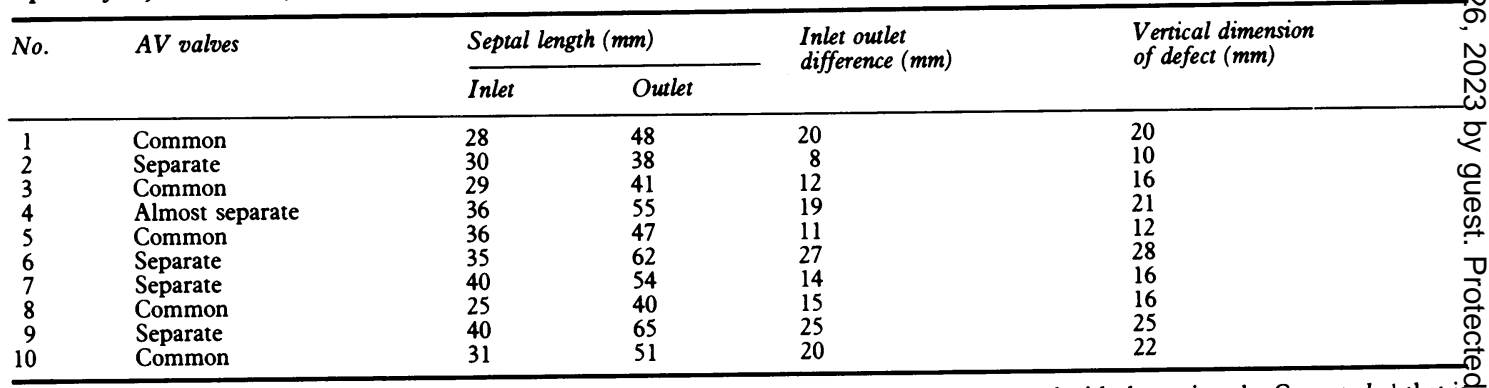

Note: The discrepancy is much the same as the vertical dimension of the defect, and the figures accord with those given by Goor et al., ${ }^{1}$ that is that there is about $30 \%$ difference between the two. Thus the inlet septum represents about one third of the septal mass. 
tional" group are like those with "partial" atrioventricular septal defect because they have two separated valves, but they also resemble "complete" atrioventricular septal defect because they have an interventricular communication.

With respect to the interventricular communication, the authors considered it to represent a deficiency of the membranous part of the septum. ${ }^{1720}$ This structure, however, is usually present and intact in atrioventricular septal defect though it is abnormally located ${ }^{5}$ (Fig. 2b).

\section{(1) VENTRICULAR SEPTUM}

In order to correlate the features described, it is necessary to describe the inlet ventricular septum and its atrioventricular component and to review recent embryological studies of ventricular septation.

The inlet ventricular septum is that part of the septum which separates the inlet portions of the left and right ventricles. It is triangular in shape (Fig. 3) and is identified in both ventricles as the smooth septum posterior and superior to the papillary muscles. On the right ventricular surface its boundaries are the tricuspid annulus and the chordal insertion of the septal leaflet of the tricuspid valve. In the left ventricle the boundaries are less well defined as the inlet septum coalesces with the trabecular septum, which extends basally to the membranous part of the ventricular septum.

The atrioventricular septum: the leaflets of both atrioventricular valves are attached to the inlet ventricular septum; because the tricuspid leaflets are attached slightly more towards the apex than those of the mitral valve, a part of the inlet musculature interposes between the right atrium and the left ventricle.
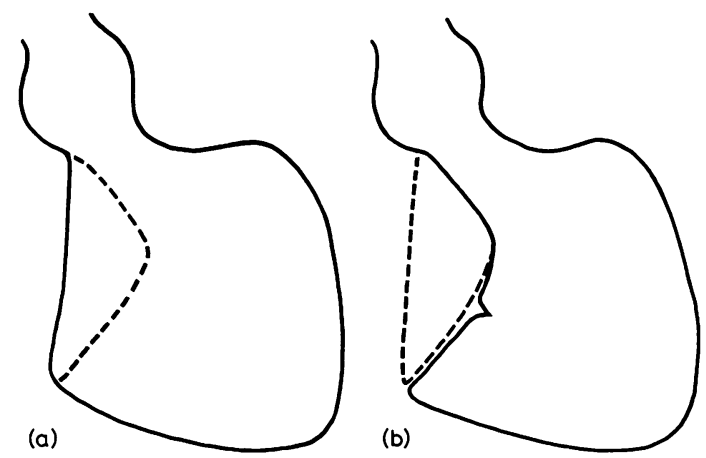

Fig. 3 (a) Diagrammatic outline (from a left ventricular angiocardiogram) to show the position of the inlet septum. It is wedge-shaped and occupies the area between the mitral valve and the outlet septum (broken lines). (b) The same view in AVSD. The left valve (solid line), notched to indicate gap between the leaflets (the cleft), has "descended" into the left ventricle. The broken lines represent the deficient inlet septum.
This is the muscular atrioventricular septum. It lies below and posterior to the membranous part of the septum, and is distinct from it (Fig. 2a). It extends from its points of coalescence with the trabecular and membranous septa to the crux cordis, producing a well defined posterior recess behind the anterior mitral leaflet. This recess not only gives an anteroposterior dimension to the left ventricular outflow tract but also contributes to the normal wedged position of the aortic valve between the two ventricular inlets and the atrioventricular valves. ${ }^{78}$

Normal cardiac septation: the ventricular septum, as its adult morphology suggests, is multifocal in origin. ${ }^{21-27}$ Before septation has begun the inlet and outlet parts of the ventricular loop are distinguishable from one another, and both contribute to the two adult ventricles. ${ }^{24}$ As the loop elaborates an inlet-outlet foramen becomes recognisable between the two limbs of the loop. This foramen is orientated in such a manner that subsequent septation will place its basal portion in the left ventricle and the apical part in the right ventricle. According to Wenink ${ }^{27}$ some of the anterior leaflet of the mitral valve elaborates from endocardium from the apical part. The inlet part of the septum develops from loose trabeculations in the posterior wall of the embryonic ventricular mass, while the outlet septum develops from cushions in the outlet part and subsequent infolding of the walls of the outlet. ${ }^{28}$

By 33 to 34 days ( $7.5 \mathrm{~mm}$ crown-rump) trabeculations appear in the posterior ventricular wall. By 43 days ( $15 \mathrm{~mm}$ crown-rump) these have coalesced to divide the inlet portions of the ventricle. This new inlet septum is obvious at $25 \mathrm{~mm}$ ( 53 days), and by this time the process of undermining of the myocardium which will form the atrioventricular valves and their papillary muscles is under way. ${ }^{26}$ By $28 \mathrm{~mm}$ this undermining is well advanced and the trabecular septomarginalis is emancipated from the septal myocardium. In the adult heart no tensor apparatus is found anterior to the trabecular septomarginalis.

The endocardial cushions, for so long considered to be precursors of the atrioventricular valves and to play a major part in both atrial and ventricular septation, ${ }^{48}$ are prominent embryonic cell masses which are first distinguishable at 29 days $(3.6 \mathrm{~mm}){ }^{26}$ They function as valves in the embryonic heart ${ }^{29}{ }^{30}$ and have regressed by the time ( 53 days) the atrioventricular valves have elaborated from the ventricular myocardium. This, according to Van Gils, ${ }^{30}$ is their primary function and they have no role in the septation of the inlets or in forming the adult atrioventricular valves.

(2) ATRIAL SEPTUM

The sequence of events which septate the atria begins fractionally later than that of the ventricles. The sep- 
Table 3 Timing of events in normal cardiac septation

\begin{tabular}{|c|c|c|}
\hline $\begin{array}{l}\text { Gestational } \\
\text { age }(d)\end{array}$ & $\begin{array}{l}\text { Crown-rump } \\
\text { length }(\mathrm{mm})\end{array}$ & Event \\
\hline $29-30$ & 3.6 & $\begin{array}{l}\text { Atrioventricular canal, endocardial } \\
\text { cushions, inlet outlet foramen }\end{array}$ \\
\hline 32 & 5 & $\begin{array}{l}\text { Septum primum, ostium primum, } \\
\text { endocardial cushions }\end{array}$ \\
\hline $33-34$ & $7 \cdot 5$ & $\begin{array}{l}\text { Ventriculobulbar septum, posterior } \\
\text { trabeculations visible, right part of } \\
\text { atrioventricular canal in direct contact } \\
\text { with outlet of future right ventricle }\end{array}$ \\
\hline 36 & 10 & $\begin{array}{l}\text { Ostium primum almost obliterated: } \\
\text { septum primum degenerates, ostium } \\
\text { secundum formed }\end{array}$ \\
\hline 43 & 15 & $\begin{array}{l}\text { Posterior trabeculations form inlet } \\
\text { septum, some begin coalescence to } \\
\text { form atrioventricular valves }\end{array}$ \\
\hline 46 & 18 & $\begin{array}{l}\text { Septum secundum meets septum } \\
\text { primum anteriorly; septum primum } \\
\text { forms foramen ovale }\end{array}$ \\
\hline 53 & 25 & $\begin{array}{l}\text { Endocardial cushions rapidly regressing, } \\
\text { myocardial undermining emancipates } \\
\text { trabecular septomarginalis and } \\
\text { atrioventricular valves }\end{array}$ \\
\hline 240 & Birth & $\begin{array}{l}\text { Foramen ovale (septum primum) } \\
\text { usually closes }\end{array}$ \\
\hline
\end{tabular}

tum primum and endocardial cushions are evident at 32 days $(5 \mathrm{~mm})$ and the ostium primum is almost obliterated by 36 days $(10 \mathrm{~mm}) .{ }^{31}$ The septum primum then degenerates to permit a second pathway, the ostium secundum. At about 46 days ( $18 \mathrm{~mm}$ ) the septum secundum meets the septum primum anteriorly to form a new opening - the foramen ovale. As is universally recognised, atrial septation is not completed until a short time after birth. Cardiac septation is summarised in Table 3.

\section{Hypothetical development of atrioventricular septal defect}

From the foregoing review of normal septation it is possible to hypothesise a developmental background for atrioventricular septal defect.

Although the atrioventricular valve deformities are of supreme surgical importance, in anatomical terms they are secondary to and consequent upon the malformation of the ventricular septum.

\section{DEFECT OF INLET SEPTUM}

Abnormal development of the posterior ventricular wall produces a deficiency of the posterior, inlet septum. Because the atrioventricular valves also develop from the posterior myocardium, they are automatically deformed when the posterior septum is deficient. A small degree of posterior maldevelopment might result in a modest defect below and behind the valves, usually called a "canal type defect". ${ }^{32}$ Most "canal type defects" are in fact excavated malalignment/ perimembranous defects, ${ }^{5}$ but where there is a genuine inlet/outlet discrepancy of the left ventricle, they are true atrioventricular defects. ${ }^{7} \mathrm{~A}$ bigger post- $\frac{\stackrel{2}{7}}{2}$ erior septal deficit would carry the valves down into $c$. the ventricles, so the gap (defect) is between them and $\vec{F}$ the floor of the atrial septum (so-called ostium $\stackrel{\text { ? }}{?}$ primum atrial septal defect). A huge deficit, readily measured anatomically (Table 1), permits the big $\frac{\bar{O}}{\bar{N}}$ interventricular communication extending as far for- $\vec{\nabla}$ wards as the anterior septum. The septal deficiency is large enough to leave the valves behind, so that the $\%$ major leaflets of the common valve float, bridging the $\vec{\circ}$ septal deficit. Because the anterior mitral leaflet elaborates from the outlet part of the loop, it remains high $\vec{\omega}$ in the left ventricle, sometimes attached to the posterior rim of the outlet septum and the aortic valve (Fig. 4a, b).

\section{ADDITIONAL ANOMALIES}

Because the inlet/outlet foramen develops before the inlet septum, coincidental maldevelopment of this region would just antedate inlet septum deficiency. As $\vec{z}$ the foramen is orientated before its septation, @ myocardial cells are carried to the basal part of the left ventricle. In normal development these contribute to $\mathscr{\emptyset}$ the anterior mitral leaflet. The same probably occurs ? in atrioventricular septal defect, permitting attachment of the left valve beneath the aortic valve when the defect is small. If the deficiency of the inlet septum is large, however, then the aortic valve may lose its anchorage in the left ventricle and become a right $\stackrel{\mathbb{Q}}{\mathscr{2}}$ ventricular structure. Maldevelopment of the outlet $\vec{\overrightarrow{ }}$ septum such as anterior deviation of the outlet (bulbar) cushions would produce infundibular obstruction such as that in Fallot's tetralogy ${ }^{33}$ and this may be exacerbated by muscle bands and abnormal placement and development of the trabecula septomarginalis. ${ }^{34}$

The final morphology of atrioventricular septal defect is determined by two factors-the extent of posterior septal deficiency governs the size of the defect (and probably the valve morphology too) while the degree of maldevelopment of the ventriculo- 9 infundibular cushions dictates the morphology of the $\frac{7}{0}$ outflow tracts.

\section{Correlates}

\section{(1) VENTRICULAR SEPTUM IN} ATRIOVENTRICULAR SEPTAL DEFECT The anatomical hallmarks of atrioventricular septal defect are deficiency of the triangular inlet septum and absence of its atrioventricular component. Deficiency of the inlet septum is shown by the short diaphragmatic surface, which is represented internally by $\overrightarrow{\mathbb{D}}$ the concave appearance of the septal surface $\frac{\Omega}{\widetilde{T}}$ (Fig. 4a, b). Absence of the atrioventricular part of $\varrho$ the inlet ventricular septum is shown by three abnor 


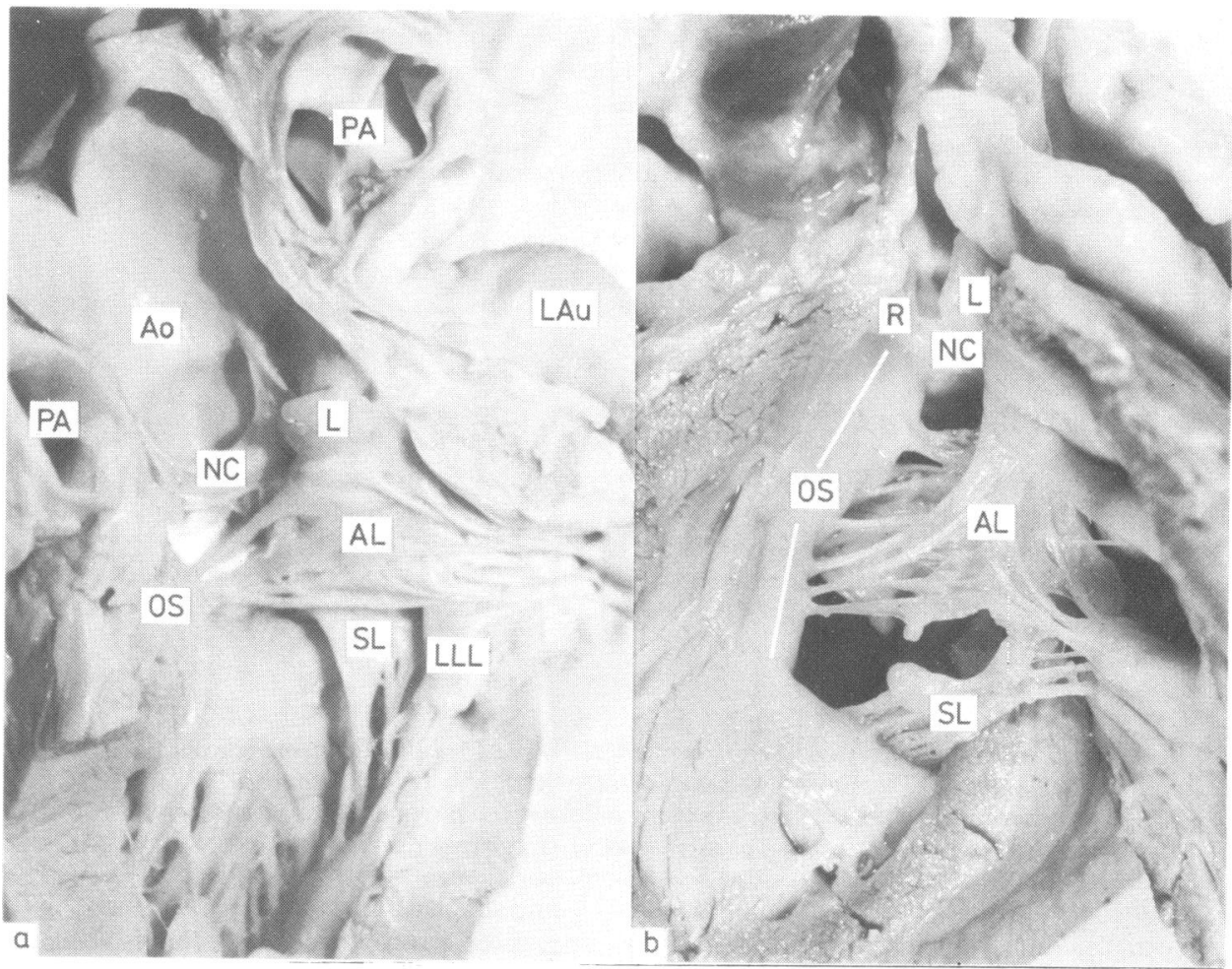

Fig. 4 (a) Left ventricular view of a small AVSD (the same heart as in Fig. 1). The left valve is attached to the rim of the outlet septum. The defect of the inlet septum (transilluminated), although quite small, is large enough to cause the abnormal orientation and attachment of the valve leaflets. PA, pulmonary artery. (b) Left ventricular view of large AVSD. There is no inlet portion and the outlet septum is very attenuated. The inlet deficit extends above, below, and behind the left valve. The anterior leaflet of the valve is attached by secondary chordae tendineae to the rim of the outlet septum, while those of the septal leaflet insert into the summit of the remaining septum. Other abbreviations as in Fig. 1.

malities. These are the abnormal plane of the atrioventricular valve(s), which are attached at the same point to the septum (Fig. 1a, b), the loss of anteroposterior dimension to the left ventricular outflow tract (Fig. 2a, b), and the abnormal position of the aortic valve. This structure is no longer wedged between the ventricular inlets, but lies anterior and superior to the atrioventricular valve leaflets (Fig. 2b, 4b). All these features indicate defective development of the inlet septum and absence of its atrioventricular component. Specimens without an interatrial communication ("canal-type" ventricular septal defects) have in the past been excluded from the compass of the malformation under review ${ }^{32}$ but, if there is a disproportion between the inlet and the outlet lengths of the left ventricle, they can be classified as examples of atrioventricular septal defect. ${ }^{7}$

\section{(2) ATRIOVENTRICULAR VALVES}

Because the valves develop from the posterior wall of the embryonic heart and some elements of the inlet/ outlet cushions they are obligatorily malformed when the embryonic structures develop abnormally. Their myocardial origin is often suggested by the muscular anomalies of both chordae tendineae and papillary muscles in atrioventricular septal defect (Fig. 5). Valve morphology accords with the degree of posterior septum deficit - two orifices usually occur with a fairly small defect and the severest form of the malformation has the free floating leaflets of the common valve sometimes predominantly opening into one or other ventricle and the huge defect both behind, below, and in front of the common valve (Fig. 4b). The plane of the valves or valve, always abnormal in atrioventricular septal defect, is governed in part by the size of the remnant of the inlet septum. Usually the valves are attached to this structure so that they "descend" to an undue extent into the ventricles. Thus there is a gap where the septum should be, and interatrial or ventriculoatrial shunting occurs through this gap.

Ventriculoatrial shunting may also occur through 
the "cleft" in the left valve. The disposition of leaflet tissue is abnormal in atrioventricular septal defect so that the left valve leaflets are abnormally orientated. The anterior leaflet itself is not cloven but is always intact-the cleft is the tissue deficit between the anterior and posterior (septal) leaflets of the valve (Fig. 6a, b). The degree of deficit, however, does not necessarily influence the function of the valve. ${ }^{35}$

Double orifice left atrioventricular valve results from an extra deep scallop (cleft) between either the anterior and lateral or the lateral and posterior leaflets, respectively, and a bridge of tissue between the two leaflets. Deep scallops (clefts) are sometimes found in normal hearts, especially in the tricuspid valve, ${ }^{36}$ and reflect the undermining process which modelled them.

Parachute mitral valve, present in about $7 \%$ of cases, ${ }^{37}$ results from inadequate liberation of the future papillary muscles from the posteromedial embryonic wall.

\section{(3) AORTIC OUTFLOW TRACT}

The pathognomonic appearance of the left ventricular outflow tract results from posterior septal deficiency (the "scooped-out" appearance) ( $^{6}$ and the abnormal attachment, often with short, thick chordae, ${ }^{38}$ of the anterior left leaflet to the remaining outlet septum. Because this septum does not have its normal smooth continuity with the infundibular septum, the myocardium in the outflow tract attenuates, giving the characteristic tunnel-like outflow tract (Fig. 4b).
The displacement of the aortic valve is probably real; if the atrioventricular septum is absent, then thea aortic valve is further superior and to the right than in $\overline{8}$ normal hearts, as it is no longer wedged between the two atrioventricular valves.

(4) PULMONARY OUTFLOW TRACT Fallot's tetralogy and atrioventricular septal defect are an uncommon combination; the hypothesis offered ${ }_{\infty}^{\bar{\Phi}}$ concerning the inlet septal maldevelopment does not? contradict the generally accepted views about the ontogeny of the infundibular malformation. ${ }^{33} 34$

\section{(5) ATRIAL SEPTUM}

The atrial septum is often normally developed in? atrioventricular septal defect, and this also lends sup- $-\frac{7}{0}$ port to the view that the malformation concerns the ventricular septum. None of the widely accepted $\tilde{}$ views about atrial septation is challenged-rather, $N$ these views are supported. Defective atrial septation has never satisfactorily explained atrioventricular sep- $\omega$ tal defect. Despite the usual cognomen "atrioventricular canal" the malformation does not remotely? resemble the arrangement in the newly-loopedos embryonic heart. Arrested or abnormal development of this region cannot explain the malformation of the outflow tract of the left ventricle, which may be mild市 or severe, but is always present.

Common atrium does, of course, represent $\stackrel{\circ}{\circ}$ rudimentary atrial septation, and is usually associated 


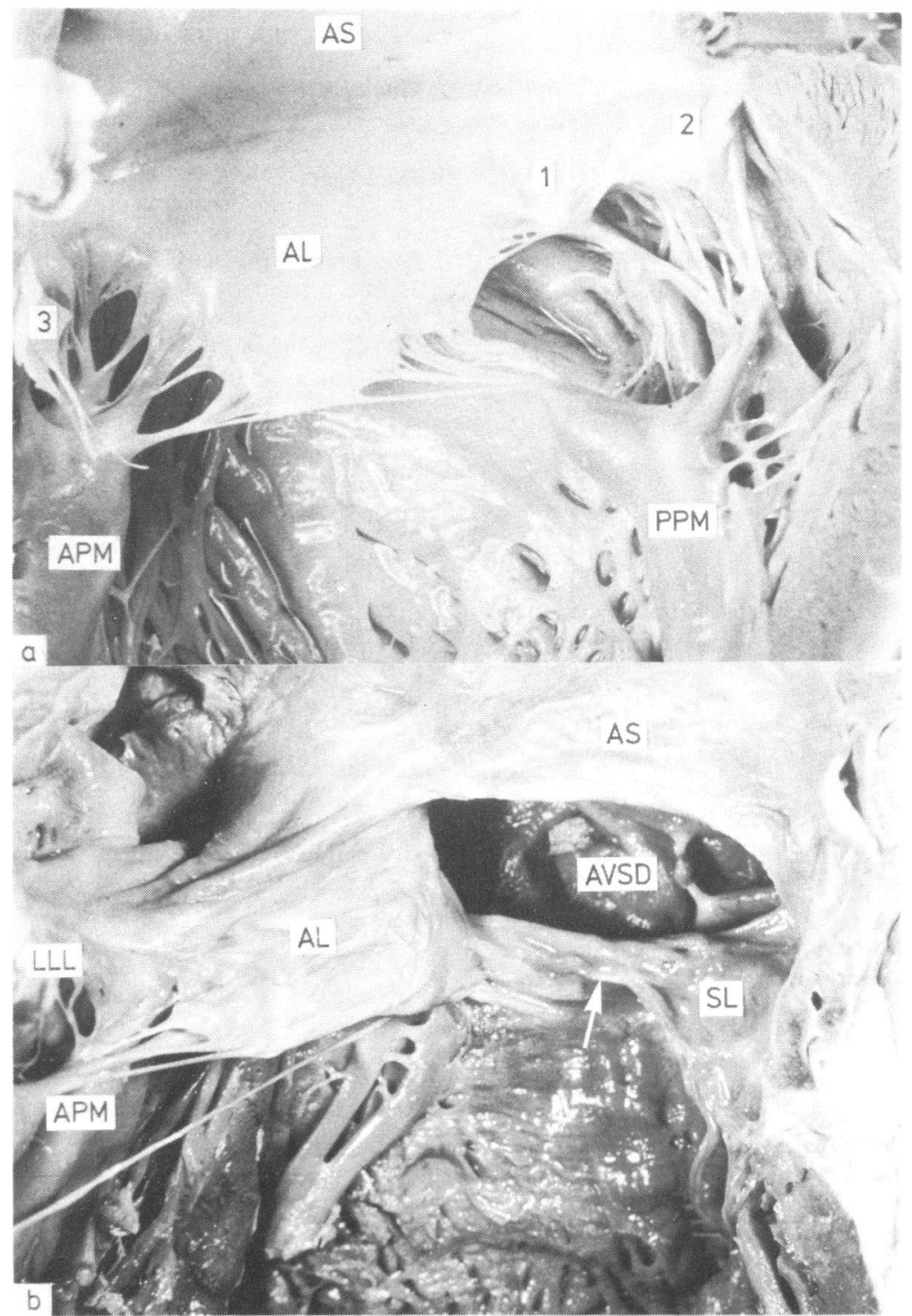

Fig. 6 (a) The left ventricular inflow in the normal heart. The anterior mitral leaflet is supported by both papillary muscles; the posterior leaflet is characteristically scalloped $(1,2$, 3). The anterior leaflet completely covers the upper third of the ventricular septum and leaflet tissue is continuous around the annulus. (b) Lefi ventricular inflow in AVSD. The anterior leaflet of the left valve is almost at right angles to the normal structure in (a) so that the upper third of the ventricular septum is visible. The leaflet is supported only by the anterior papillary muscle group - the remainder of the leaflet inserts into the posterior wall of the outlet septum. Distinct septal and lateral leaflets are recognised. Although there is valve tissue on the summit of the ventricular septum there is a gap (the cleft, arrowed) between the anterior and septal leaflets. The anterior leaflet is never split-clefts are the spaces between the leaflets. PPM, posterior papillary muscle group; $A P M$, anterior papillary muscle group. Other abbreviations as in Fig. 1. 
with the more severe forms of atrioventricular septal defect (Fig. 6). There seems no reason to suppose any more elaborate mechanism than defective atrial septation to explain this coexistence.

\section{Conclusion}

The embryological studies reviewed here shed light on the developmental background of the ventricular septum and the atrioventricular valves. The embryology of the anatomical touchstones of atrioventricular septal defect has been hypothesised, and this hypothesis challenges neither the accepted views about atrial septation nor about outflow tract maldevelopment which may coexist.

\section{References}

1 Goor D, Lillehei CW, Edwards JE. Further observations on the pathology of the atrioventricular canal malformation. Arch Surg 1968; 97: 954-62.

2 Rastelli GC, Kirklin JW, Titus JL. Anatomic observations on complete form of persistent common atrioventricular canal with special reference to atrioventricular valves. Mayo Clin Proc 1966; 41: 296-308.

3 Carpentier A. Surgical anatomy and management of the mitral component of atrioventricular defects. In: Anderson RH, Shinebourne EA, eds. Paediatric cardiology 1977. Edinburgh, London, \& New York: Churchill Livingstone, 1978: 477-90.

4 Van Mierop LHS, Alley RD, Kausel HW, Stranahan A. The anatomy and embryology of endocardial cushion defects. F Thorac Cardiovasc Surg 1962; 43: 71-83.

5 Piccoli GP, Gerlis LM, Wilkinson JL, Lozsadi K, Macartney FJ, Anderson RH. Morphology and classification of atrioventricular defects. Br Heart $\mathcal{F}$ 1979; 42: 621-32.

6 Piccoli GP, Wilkinson JL, Macartney FJ, Gerlis LM, Anderson RH. Morphology and classification of complete atrioventricular defects. Br Heart $\mathcal{F}$ 1979; 42: 6339.

7 Anderson RH, Wilkinson JL, Macartney FJ, et al. The anatomy and conduction tissues of atrioventricular defects. In: Gallucci V, Bini RM, Thiene G, eds. Selected topics in cardiac surgery. Bologna: Patron Editione, 1980: $11-35$.

8 Van Mierop LHS. Pathology and pathogenesis of endocardial cushion defects, surgical implications. In: Davila JL, ed. Second Henry Ford Hospital intermational symposium on cardiac surgery. New York: AppletonCentury-Crofts, 1977: 201-7.

9 Draulans-Noë HAY. Echocardiography and angiocardiography in atrioventricular defects (abstract). In: The ventricular septum. Leiden: Boerhaave Committee for Postgraduate Medical Education, 1980: 57-61.

$10 \mathrm{Lev}$ M, Agustsson MH, Arcilla R. The pathologic anatomy of common atrioventricular orifice associated with the tetralogy of Fallot. Am f Clin Pathol 1961; 36: 408-16.
11 Sridaromont S, Feldt RH, Ritter DG, Davis GD, ® McGoon DC, Edwards JE. Double-outlet right ventricle $\stackrel{c}{c}$ associated with persistent common atrioventricular canal. Circulation 1975; 52: 933-42.

12 Thiene G, Frescura C, Di Donato R, Gallucci V. Complete atrioventricular canal associated with conotruncal malformations: anatomical observations in 13 specimens. Eur f Cardiol 1979; 9: 199-213.

13 Peacock TB. Malformation of the heart consisting of an imperfection of the auricular and ventricular septa. is Transactions of the Pathological Society of London 1846; 1: 61-2.

14 Rokitansky C. Die Defekte der Scheidewände des Herzens. Pathologisch-anatomisch Abhandlung. Vienna: Braumuller, 1875.

15 Rogers HM, Edwards JE. Incomplete division of the atrioventricular canal with patent interatrial foramen primum (persistent common atrioventricular ostium). Report of five cases and review of the literature. Am Heart f 1948; 36: 28-54.

16 Watkins E, Gross RE. Experience with surgical repair of 5 atrial septal defects. $\mathcal{F}$ Thorac Surg 1955; 30: 469-91.

17 Wakai CS, Edwards JE. Developmental and pathologic considerations in persistent common atrioventricular 2 canal. Proceedings of the Staff Meetings of the Mayo Clinic 1956; 31: 487-500.

18 Bedford DE, Sellors TH, Somerville W, Belcher JR, Besterman EMM. Atrial septal defect and its surgical treatment. Lancet 1957; 2: 1255-61.

19 Brandt PWT, Clarkson PM, Neutze JM, Barratt-Boyes BG. Left ventricular cineangiocardiography in endocardial cushion defect (persistent common atrioventricular $\mathbb{D}$ canal). Australas Radiol 1972; 16: 367-76.

20 Wakai CS, Edwards JE. Pathologic study of persistent common atrioventricular canal. Am Heart $\mathcal{F}$ 1958; 56: 779-94.

21 Goor DA, Edwards JE, Lillehei CW. The development of the interventricular septum of the human heart. Correlative morphogenetic study. Chest 1970; 58: 453-67.

22 Goor DA, Lillehei CW, Rees R, Edwards JE. Isolated? ventricular septal defect. Development basis for various types and presentation of classification. Chest 1970; 58: 468-82.

23 Wenink ACG. Considerations pertinent to the embryogenesis of transposition. In: Van Mierop LHS, Oppenheimer-Dekker A, eds. Embryology and teratology of the heart and great arteries. Leiden: University Press, 1978: 129-35.

24 Wenink ACG, Oppenheimer-Dekker A, Moulaert AJ. Muscular ventricular septal defects, a reappraisal of the anatomy. Am F Cardiol 1979; 43: 259-64.

25 Bersch W. On the importance of the bulboauricular flange for the formal genesis of congenital heart defectso with special regard to the ventricular septum defects 0 Virchows Arch [Pathol Anat] 1971; 354: 252-67.

26 Wenink ACG. Embryology of the ventricular septum. Virchows Arch [Pathol Anat] 1981; 390: 71-9.

27 Wenink ACG. Multifocal origin of the ventricular sep- -0 tum (abstract). In: The ventricular septum. Leiden:这 Boerhaave Committee for Postgraduate Medical Education, 1980.

28 Anderson RH, Becker AE. Cardiac anatomy. London:

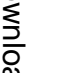

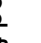


Gower, 1980: 10.13-10.19.

29 Van Gils FAW. The formation of the atrioventricular heart valves (abstract). Acta Morphol Neerl Scand 1978; 16: 151.

30 Van Gils FAW. The development of the human atrioventricular heart valves (abstract). F Anat 1979; 128: 427.

31 Hamilton WJ, Mossman HW. Hamilton Boyd and Mossman's human embryology. 4th ed. Cambridge: Heffer \& Sons, 1972: 228-90.

32 Neufeld HN, Titus JL, DuShane JW, Burchell HB, Edwards JE. Isolated ventricular septal defect of the persistent common atrioventricular canal type. Circulation 1961; 23: 685-96.

33 Becker AE, Connor M, Anderson RH. Tetralogy of Fallot: a morphometric and geometric study. Am $\mathcal{F}$ Cardiol 1975; 35: 402-12.

34 Anderson RH, Allwork SP, Ho SY, Lenox CC, Zuberbuhler JR. The surgical anatomy of the tetralogy of Fallot. F Thorac Cardiovasc Surg 1981; 81: 887-96.
35 Somerville J. Clinical assessment of the function of the mitral valve in atrioventricular defects related to the anatomy. Am Heart $\mathcal{J}$ 1966; 71: 701-11.

36 Allwork SP, Anderson RH. Development anatomy of the membranous part of the ventricular septum in the human heart. Br Heart f 1979; 41: 275-80.

37 Freedom RM. In: Gallucci V, Bini RM, Thiene G, eds. Selected topics in cardiac surgery. Bologna: Patron Editione, 1980: 98.

38 Edwards JE. The problem of mitral insufficiency caused by accessory chordae tendineae in persistent common atrioventricular canal. Proceedings of the Staff Meetings of the Mayo Clinic 1960; 35: 299-305.

Requests for reprints to Dr S P Allwork, Department of Surgery, Royal Postgraduate Medical School, Ducane Road, London W12 0HS. 